\title{
COLOR ANALYSIS OF NASAL MUCOSA
}

\author{
AKIRA TERAO, M.D. \& YASUO SATO, M.D. \\ Department of Otolaryngology, University of Tokyo, Faculty of Medicine, Tokyo.
}

(Director: Y. Sato, M.D.)

Color analysis of nasal mucosa was done by visual comparison with Munsell's Color Standards. The results were summarized as follows:

1) Hue was distributed from $2.5 \mathrm{R}$ to $7.5 \mathrm{RP}$. The maximum incidence was found in the range of $7.5 \mathrm{RP}-10 \mathrm{RP}$ on the lower turbinate and in $10 \mathrm{RP}-2.5 \mathrm{R}$ on the nasal septum.

2) Value range of the lowwer turbinate was $6-8$, and of the nasal nasal septum was 5-7.

3) Chroma range of the lower turbinate was 4-10, and of the nasal septum was 8-12.

4) Value and Chroma of allergic pale nasal mucosa were 8 and 4, and those of reddish nasal mucosa in acute rhinitis were 6 and 10 respectively.

A78-0501. 32083

\section{鼻粘膜の色彩に関する研究}

東京大学医学部耳鼻咽喉科学教室 (主任 : 佐藤踋雄教授)

寺尾彬・佐 藤 靖 雄

\section{I 舶言}

番粘膜の色を，血管病変との関連において観察した Bernheimer1) の論文を読むと, 鼻粘膜の色は, normal color, red, pale といら言葉で三型に分類され表現され ている.たしかに鼻粘膜の色はいろいるな疾患によつて 異なつている，例えば急性鼻炎の症例を視診すると粘膜 は赤みが著しく，アレルギー性鼻炎では荅白色となつて いる場合が多い。

日常臨床において粘膜色俚このように表現されてい て, また実際にこの程度の記載で充分理解できるのであ るが, 色彩学的立場から赤いとか荅白とかいう表現を考 えてみると，これは極めて䁓昧なむのであ万らと推察さ れる.

一体覓粘膜の色とは色彩学的に注どのような色をさす ことになるのであろらか。亦たそれは多種にわたる色全 体のらちでどのような位圈を占めているのであろうか． 本論文で注鼻粘膜色の診断的価值が大きいところから， これら疑問点の解明を研究課題としてみた。

\section{II 色の表示方法 (表色) $)^{2}$}

色の表示方法には次のような種類がある.
1）色名による表示方法

2）波長比よ表示方法

3）三属性による表示方法（日本工業規格 JIS Z 8721）

4) $\mathrm{XYZ}$ 系 (CIE 系) に上る表示方法 (日本工業規 格 JIS $Z$ 8701)

このうち本研究の表示は，3，4）の方法によつた. 三属性による表示方法とは，色を心理物理的な三属性す なわち色相 $\mathrm{H}$ (hue), 明度 V (value), 彩度 C (chroma) といらアメリカの A.H. Munsell が発案した記号によ つて表示する方法である。

XYZ 系による表示方法とは 1951 年の国際照明委員会 C.I.E. (Commission Internationale de l'Eclairage) の 決議に基づいた表示であり，物理的測定からその表示値 を算出する方法である，そして現在この方法が最む精密 な心理物理的な表示法といわれている．XYZとは目の 三種の感光機構の感じた量,つまり試料色に含まれる赤 緑青の分量を三刺激値と名うけこれを XYZ と呼んでい る. さらに XYZの值加ら, 三属性記号への変換可可能 である。

\section{III 分光計算 $(\text { 色度計算 })^{3)}$}


物理的な分光特性を測定し，三刺激值 XYZ を求める 計算を分光計算または色度計算といら，XYZ 系の表示 は次の式により求められる。

$$
\begin{aligned}
& \mathrm{X}=k \sum_{880}^{780} P_{\lambda} \rho_{\lambda} \bar{x}_{\lambda} \Delta \lambda \\
& \mathrm{Y}=k \sum_{880}^{780} P_{\lambda} \rho_{\lambda} \bar{y}_{\lambda} \Delta \lambda \\
& \mathrm{Z}=k \sum_{880}^{780} P_{\lambda} \rho_{\lambda} \bar{z}_{\lambda} \Delta \lambda
\end{aligned}
$$

$x=\frac{\mathrm{X}}{\mathrm{X}+\mathrm{Y}+\mathrm{Z}} \quad y=\frac{\mathrm{Y}}{\mathrm{X}+\mathrm{Y}+\mathrm{Z}} \quad z=\frac{\mathrm{Z}}{\mathrm{X}+\mathrm{Y}+\mathrm{Z}}$

$$
k=\frac{1}{\sum_{880}^{780} P_{k} \bar{y}_{\lambda} \Delta \lambda}=\frac{1}{1,000,000}
$$

$P_{2}$ : 標準光のスペクトル分布 すなわち照明に用 いた光の波長別のエネルギー分布（定数）

$\left.\begin{array}{l}\bar{x} \lambda \\ \bar{y} \lambda \\ \bar{z} \lambda\end{array}\right\} ス ヘ ゚ ク ト ル 三$ 刺激值 (distribution cofficients)

すなわち等しいエネルギーのスペクトルの単色 光が眼に入つた場合の波長別感度（定数）

$\rho_{\lambda}:$ 試料の分光特性

$\Delta_{\lambda}$ : 波長間隔 $(10 \mathrm{~nm}=10 \mathrm{~m} \mu)$

ここで鼻粘膜色の問題に入るが，畺粘膜の色注血液の 色すなわちへモグロビンの色が反映されたるのであると 考えられる。そこで鼻粘膜色の検討の手がかりを得るた

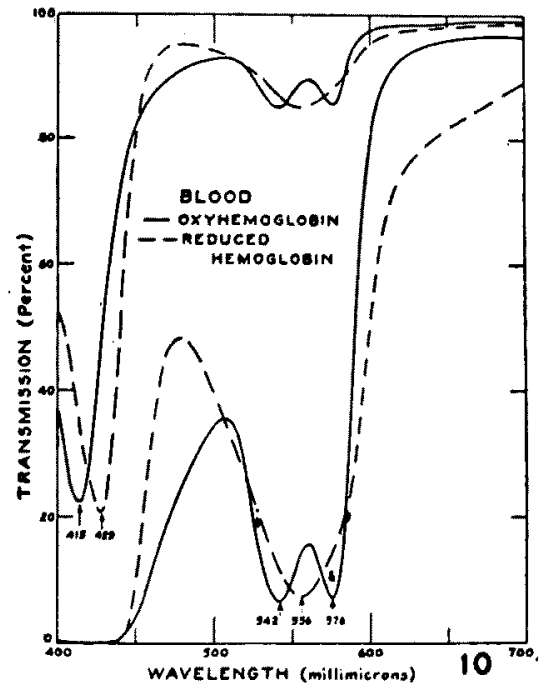

下段の $1 \%$ モモグロビン溶液の特性曲線を引用した。

図 1
めに，へモグロビンの分光特性曲線図“(図 1）加ら色度 計算を行つた。

この場合のへモグロビン特性曲線は透過色を表わすも のであり，したがって計算には比反射率 $\rho_{\lambda}$ の代りに比 透過率 $\tau_{2}$ を用いた。 つまりへモグロビン分光特性曲線 の400 700 nm の間で10nm ごとに比透過率を読みとり 表に記入した(表 1).さらにこの数值を $\mathrm{XYZ}$ を求める ために必要な定数（表 2 ）とかけあわせ次の結果を得

\begin{tabular}{|c|c|c|}
\hline$\lambda(\mathrm{nm})$ & $\mathrm{HbO}_{2} \tau_{\lambda}$ & $\mathrm{Hb} \tau_{2}$ \\
\hline 400 & 0 & 0 \\
\hline 10 & 0 & 0 \\
\hline 20 & 0 & 0 \\
\hline 30 & 0 & 0 \\
\hline 40 & 0.019 & 0.019 \\
\hline 450 & 048 & 067 \\
\hline 60 & 105 & 286 \\
\hline 70 & 171 & 476 \\
\hline 80 & 248 & 514 \\
\hline 90 & 305 & 457 \\
\hline 500 & 343 & 390 \\
\hline 10 & 362 & 324 \\
\hline 20 & 305 & 257 \\
\hline 30 & 086 & 171 \\
\hline 40 & 076 & 124 \\
\hline 550 & 114 & 086 \\
\hline 60 & 152 & 086 \\
\hline 70 & 076 & 114 \\
\hline 80 & 286 & 162 \\
\hline 90 & 524 & 295 \\
\hline 600 & 810 & 486 \\
\hline 10 & 895 & 686 \\
\hline 20 & 933 & 262 \\
\hline 30 & 952 & 800 \\
\hline 40 & 962 & 810 \\
\hline 650 & 971 & 829 \\
\hline 60 & 981 & 848 \\
\hline 70 & 981 & 860 \\
\hline 80 & 990 & 867 \\
\hline 90 & 981 & 876 \\
\hline 700 & 981 & 876 \\
\hline
\end{tabular}
た.

$$
\begin{aligned}
& \text { 酸化へモグロビン }\left(\mathrm{HbO}_{2}\right) \\
& \mathrm{X}=0.458 \quad \mathrm{Y}=0.331 \quad \mathrm{Z}=0.117
\end{aligned}
$$

\section{表 $\quad 1$}


したがつて酸化へモグロビンの色は $\mathrm{Y}=33.1 \%$ (透過率) $x=0.506 \quad y=0.365$ と表示される.

還元へモグロビン $(\mathrm{Hb})$

$$
\mathrm{X}=0.366 \quad \mathrm{Y}=0.285 \quad \mathrm{Z}=0.236
$$

したがつて還元へモグロビンの色は $\mathrm{Y}=28.5 \%$ (透過率) $x=0.412 \quad y=0.321$ と表示されることになった。

\section{IV 三属性表示}

次に XYZ 系の数值で示された色を寒際に眼でみるこ とのできる色の三属性表示へと変換した，三属性值がき まるとその色票を用意することができ，これを基にして

\begin{tabular}{|c|c|c|c|}
\hline$\lambda(\mathrm{nm})$ & $P_{2} \bar{x}_{\lambda}$ & $P_{\lambda} \bar{y}_{\lambda}$ & $P_{\lambda} \bar{z}_{\lambda}$ \\
\hline 380 & 4 & 0 & 20 \\
\hline 90 & 19 & 0 & 89 \\
\hline 400 & 85 & 2 & 404 \\
\hline 10 & 329 & 9 & 1,570 \\
\hline 20 & 1,238 & 37 & 5,949 \\
\hline 30 & 2,997 & 122 & 14,628 \\
\hline 40 & 3,975 & 262 & 19,938 \\
\hline 450 & 3,915 & 443 & 20,638 \\
\hline 60 & 3,362 & 694 & 19,299 \\
\hline 70 & 2,272 & 1,058 & 14,972 \\
\hline 80 & 1,112 & 1,618 & 9,461 \\
\hline 90 & 363 & 2,358 & 5,274 \\
\hline 500 & 52 & 3,401 & 2,864 \\
\hline 10 & 89 & 4,833 & 1,520 \\
\hline 20 & 576 & 6,462 & 712 \\
\hline 30 & 1,523 & 7,934 & 388 \\
\hline 40 & 2,785 & 9,149 & 195 \\
\hline 550 & 4,282 & 9,832 & 86 \\
\hline 60 & 5,880 & 9,841 & 39 \\
\hline 70 & 7,322 & 9,147 & 20 \\
\hline 80 & 8,417 & 7,992 & 16 \\
\hline 90 & 8,984 & 6,627 & 10 \\
\hline 600 & 8,949 & 5,316 & 7 \\
\hline 10 & 8,325 & 4,176 & 2 \\
\hline 20 & 7,070 & 3,153 & 2 \\
\hline 30 & 5,309 & 2,190 & 0 \\
\hline 40 & 3,693 & 1,443 & 0 \\
\hline 650 & 2,349 & 886 & 0 \\
\hline 60 & 1,361 & 504 & 0 \\
\hline 70 & 708 & 259 & 0 \\
\hline 80 & 369 & 134 & 0 \\
\hline 90 & 171 & 62 & 0 \\
\hline 700 & 82 & 29 & 0 \\
\hline
\end{tabular}

鼻粘膜色を比較検討することができる。ところが，色 相，明度，彩度など三属性表示は物体色の5ちでも表面 色住対してのみ使用されるもので，へモグロビンのよう な透過色に汇適応されないことになっている。

そこで上記へモグロビンと同じ XYZ 値をもった表面 色を想定して変換作業をすすめた，Y（\%) 加ら明度を 求めるのは JIS Z 8721の附表に2よつた（図2），すな わち

酸化へモグロビンの明度 6

還元へモグロビンの明度 6 となつた。

次に明度 6 の色度図 (chromaticity diagram JIS Z 8721 の附図)(図 3 ) から酸化へモグロビンの $x=0.506$, $y=0.365$ さらに還元へモグロビンの $x=0.412, y=$ 0.321 の座標を求めることにより結局次のような三属性 值を得ることができた。

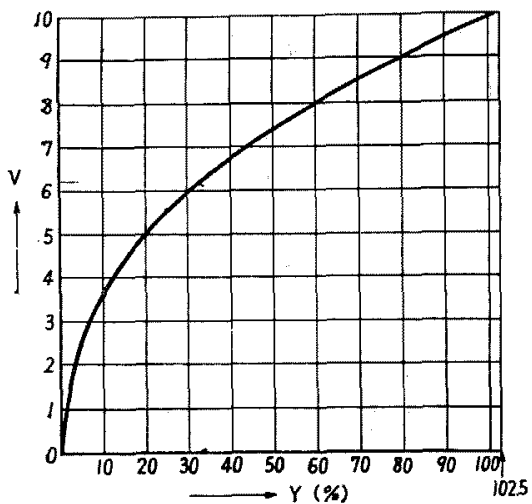

図 $2 \mathrm{Y}$ とと関俰

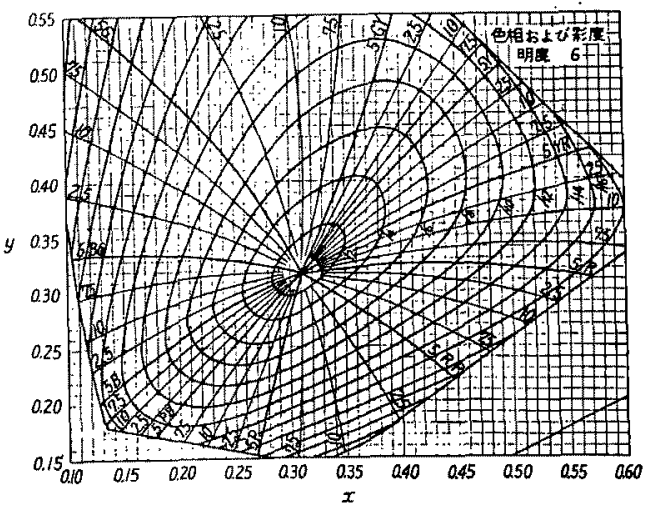

図 3 明度 6 における修正マンセル值 
酸化へモグロビン

色相 $H=10 R$

明度 $V=6$

彩度 $\mathrm{C}=11$

還元へモグロビン

色相 $\mathrm{H}=2.5 \mathrm{R}$

明度 $\mathrm{V}=6$

彩度 $\mathrm{C}=8$

\section{$\mathrm{V}$ 研究方法}

酸化還元へモグロビンにほぼ一致する色の三属性值が きまつたので, この值を中心にその周辺部も含めて色相 環上（図 4) 5RP 10R の範囲で修正マンセル色票を用 意し（図 5) これを標準にして昼光のもとで 100 例の鼻 粘膜を肉眼で比色した，その部位は下甲介および鼻中隔 の前部である. 比色を行つた者は年令30才代の男子で, 勿論色覚に異常なく色の観察にかけてはある程度練習を 積んで馿れていた。

\section{VI 研 究 結果}

1）鼻下甲介㧍よび鼻中隔の色相

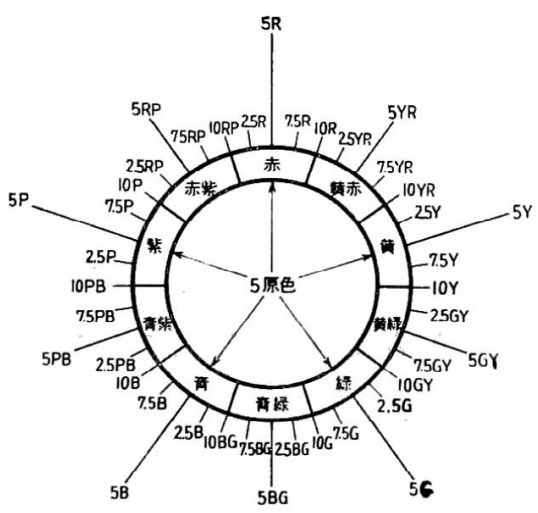

図 4 色 相 環

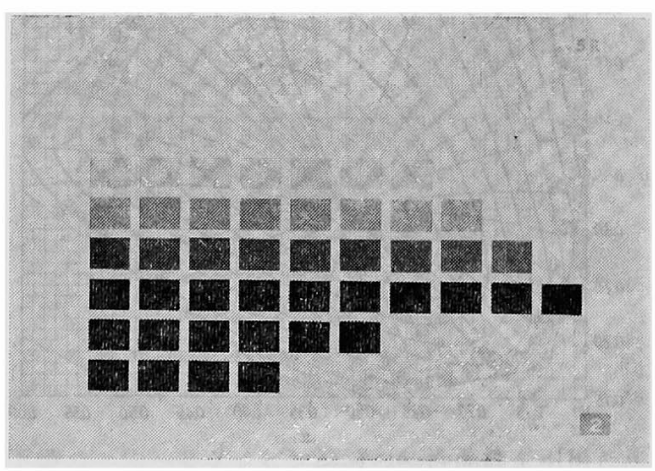

図 5 マンセル色 票
研究対象とした例の下甲介拉よび鼻中隔前 部の粘膜 の色相は, 色相環の $2.5 \mathrm{R} \sim 7.5 \mathrm{RP}$ の範囲にあり，その 内容は， 7.5RP の下甲介が46例，鼻中隔が 10 例， $10 \mathrm{RP}$ に相当する下甲介が48例，それに鼻中隔が 58 例， $2.5 \mathrm{R}$ がそれぞれ6例と32例であつた（表 3 ）。これは下甲介 の色あいが赤紫であるのに対し鼻中隔の方は赤色の例が 多いということである.

表

3

\begin{tabular}{|c|c|c|c|c|c|}
\hline 色 相 & 下 & 甲 介 & 鼻 & 中 & 隔 \\
\hline $5 \mathrm{RP}$ & & 0 & & 0 & \\
\hline $7.5 \mathrm{R} \mathrm{P}$ & & 46 & & 10 & \\
\hline $10 \mathrm{R} \mathrm{P}$ & & 48 & & 58 & \\
\hline $2.5 \mathrm{R}$ & & 6 & & 32 & \\
\hline $5 \mathrm{R}$ & & 0 & & 0 & \\
\hline
\end{tabular}

2）鼻粘膜色の明度と彩度に関する測定

この結果は図6に各色相ごとにまとめた.

表中の数值は症例数を表わしている.

なおこの測定において，いわゆるアレルギー性粘膜の 蒼白色とは, 各色相とも明度 8 , 彩度 4 附近の色をさす のに対し, 急性鼻炎粘膜の著しい発赤とは, 明度 6 彩度 10附近の色であることがわかつた。

\section{VII 考 察}

人類の生活で初めて色彩が使われたのは，およそ20万 年前の原始社会の頃と推測されている. ${ }^{5)} こ の$ 時代の穴 居生活に拉いて描かれた壁画や，骨や石で作られた細工 物には, 赤, 黄, 茶, 黒, 紫, 白などの色がつけられて いたといわれているし，わが国です，繩文式文化の堅穴 住居に色彩的配虑がなされていたことが知られている. その後古墳文化に入ると, いろいろな装飾品に, 赤, 青, 黄などのはつきりした色彩がみられるよらになつ た.

このように，人類は原始生活の頃から色に対して本能 的ともいえるよらな関心を持ち，かつそれを亨受し続け てきたわけである.

一方, この色彩の科学すなわち色彩学の発祥はどのよ らになつていたのであろらか.

イギリスの Newton が太陽光を三角プリズムにあてた 時それが 7 色スペクトルに分光することを発見したのが 1666年であり, 色彩学の歴史はこの時に始まつている. 色とは光を刺激として生ずる視感覚の一種であると定義 されているように, 純粋に物理光学の問題であると同時 

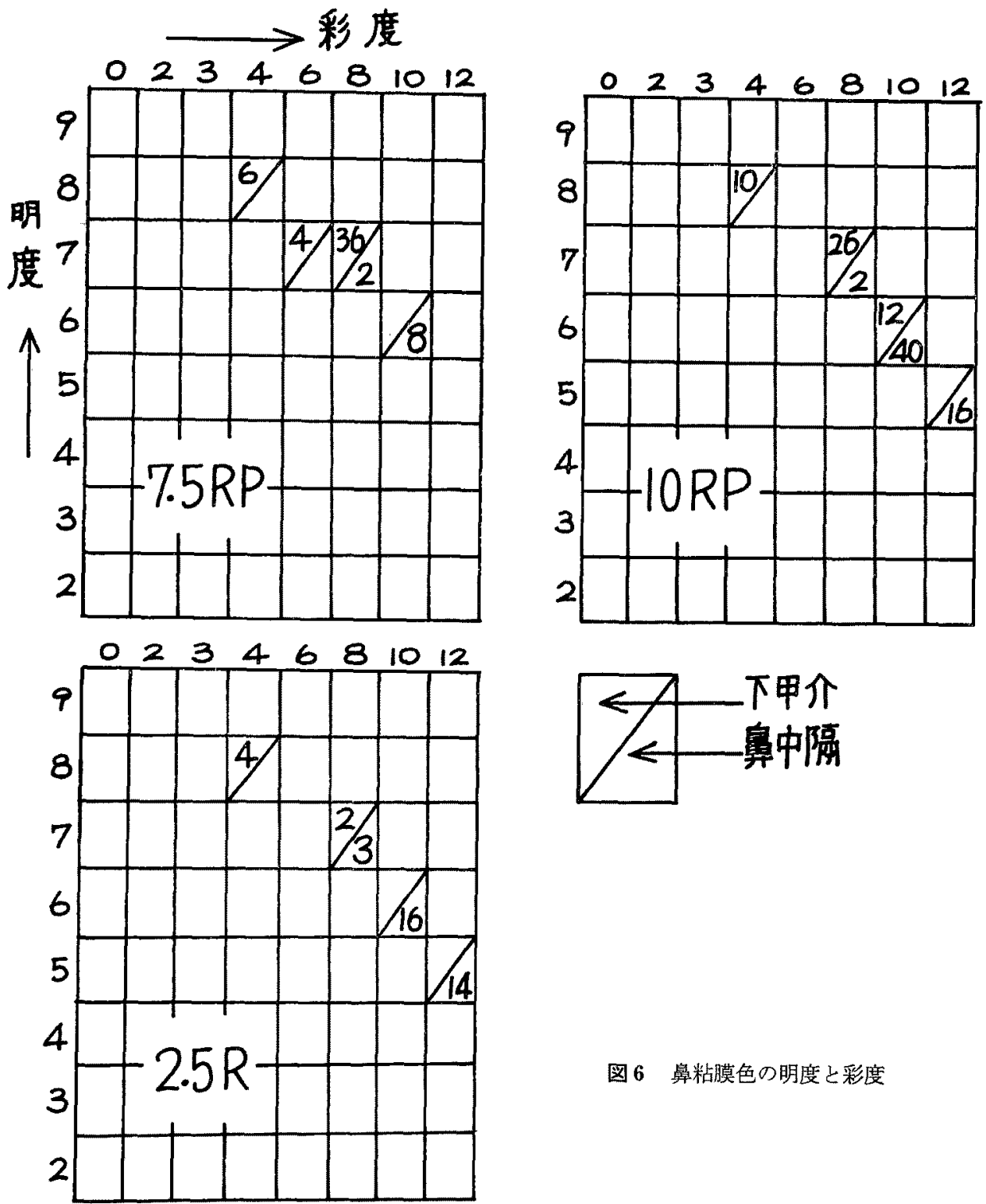

图 6 䶊粘膜色の明度と彩度

に複雑な感覚の要素が含まれている，感覚の問題を最初 に唱えたのはドイッのGoethで, 1810年にその著書「色 彩論」で色の感賞的体験を強調して Newtonの物理的 色彩説に反論したことは有名な逸話となつている，その 後 Young, Helmholz の三原色説, Wright 括上び Guild の混色実験が登場して, 次第に研究の基礎が固められた のであるが, 要するに色注, 物理学, 生理学, 心理学比 その領城を持つ科学であり，それぞれの面からのアプロ
一チが必要である。このように色彩学研究の過程には, 各種の制約が待つているのであるが，ここで本諭文の研 究方法に関連して次の $2 つ の$ 項目について断わつておき たいと思5。

第 1 は，鼻粘膜色と対比させるための標準にする色票 がどらしても必要であつた，そのために使用する色票 を，多くの種類のものからいかにして準備すればよいか といら段階で迷つた。標準色票を選択する手がかりを得 
るために，透過色のへモグロビン特性曲線から得た分光 計算結果を，便宜上，表面色のものに監き換えて一応の 三属性值を求めた。このよらにして決められた值を持つ 修正マンセル色票を標準色票として選び，鼻粘膜色とく らべた.

第 2 に，鼻粘膜という試料を直接眼で見て比較したの であるから，この過程にはかなり心理的要因が含まれて いるはずである。それにもかかわらず，ときに両者の間 で完全な色の一致が得られないことがあつた，色票およ び鼻粘膜ともに，それらの表面色を比較しているのであ るが，比較するものがお互い同質でないと，ときに色の 一致が得られないよらである。紙に顔料を塗布して作ら 机た色紙である色票と，この色紙とは異質の試料である

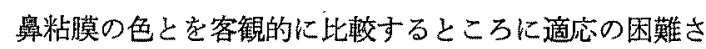
があるよ5にむ思えるのであるが，現在これ以外纪適当 な方法はなく，比色技術の面で今後に残された問題は多 いと思われる。

このような条件下に行われた研究であるが，まず鼻粘 膜の色相に関して最も興味をそそられた点は，舅粘膜は 動脈血の色を反映するものではなく、むしろ静脈血の色 に類似していることであった。 下甲介粘膜にある豊富な 静脈鋠の色が表面に映るのであるらが，さらに検討をす すめてみると，特に下甲介は，その色相が7.5RP, $10 \mathrm{RP}$ といらよらに，静脈血 $2.5 \mathrm{R} の$ 色相よりさらに紫の色調 が著しく赤紫と呼ばれる色相となつている，鼾中隔につ いては，逆に下甲介よりも赤の色がきわだつている．た だし，これも静脈血そのものの色に類似しているという ことであり，下甲介，䶊中隔の両者とも動脈血の色相に はほど遠いことがわかつた，下甲介の色が静脈血のそれ よりさらに一段と紫がかかっている理由，また鼻中隔の 方が下甲介よりも赤色が著しい理由を考察してみると， 血液を含まない鼻粘膜自体の色と粘膜の厚みが問題にな るようである、つまり，下甲介粘膜の静脈丵の色に加え て，血液を含まない粘膜そのものにも色があるはずで, この粘膜自体の色と静脈血の色とが混色合成されたもの を下甲介粘膜の色として見ているのではないかと推測さ れるのである，畜中隔については，下甲介にくらべ粘膜 が薄く，そのため静脈血の色が直接浮かんできやすい のであろう。

鼻粘膜の明度と彩度に関していえば，下甲介は，色相 $7.5 \mathrm{RP}, 10 \mathrm{RP}$ ともに明度 7 . 彩度 8 が多く, 鼻中隔は 色相 $10 \mathrm{PR}$ では, 明度6, 彩度10が，また色相 $2.5 \mathrm{R}$ では 明度 5, 彩度10〜12が多いという結果であり, 鼻中隔の
方が下甲介に比べて色の明るさはともかく，彩度は一段 と高くなつている。ここでい和ゆるアレルギー性鼻㷋の 荅白色, 急性鼻炎の著しい赤色を考察してみると, アレ ルギー性鼻炎の嚄白色とは各色相とも, 明度 8 , 彩度 4 の附近の色を指して招りここれはあざやかとはいえない が極めて明るい色と表現できる。また急性鼻炎の粘膜色 は, 明度 6 , 彩度10附近の色であり, これは明るい色と はいえないがあざやかな色といらことができる、そして 正常群の粘膜色注明度彩度ともアレルギー性鼻炎と急性 悬炎粘膜色の中間を占めていることになる.

血液を含まない鼻粘膜の色がどのような物筫の影響を らけるか現在よくわかつていないが，皮虞にはメラニ ン，カロチンなどの色素が含有されており，血液の色と ともに皮膚の色纪変化を与えている.日本人の皮虞の色 域についてはこれを測定した結果(6)によると，色相 2.5 YR 5YR に最大出現率がみられ，10R附近の例も多い， これは, 前額, 煩部, 手背, 前腕屈側部における色の分 布の平均值であるが，肉眼的には黄赤色である，この皮 㲊の黄赤色と䶊粘膜の赤紫色とを比較してみると，色相 環で赤の $5 \mathrm{R}$ を軸にして耐者は丁度対照的位置を占めて いる(図4).

以上, 舅粘膜の色彩, とくに色相, 明度, 彩度などの 三属性について述べてきたが，次に比色法の問題につい て簡単にふれてみることにしたい

色の比較方法は，見本色と試料色とを肉眼で見る視感 比色法上光電管に依存する光電比色法に大別される ${ }^{3), 7) . ~}$ このうち後者の光電比色法注，さらに刺激値值読法と分 光測色法に分れ，それぞれ光電色彩計，分光光度計が使 われる.したがつて光電比色法の方が，視感比色法より 精度は高いのであるが，構造上，これを鼻腔内に挿入す ることは不可能である，先年，著者等は，試料に接触す る部分のみを小型化する器械を試作したが，皮䖉の場合 と同様で粘膜に当てた時の接触圧の如何で血流変動を誘 発し，測定誤差の処理に困惑したことがある.

鼻粘膜の測色の信頼性は，鼻腔の構造に適合した光電 器械の開発によつて飛躍的に高まるはずであり，これが 興味ある研究課題にもなるであろう。

\section{文献}

1) Bernheimer, L.B.: Color index of the nasal septum. Arch Otolaryng., $20 ; 31,1934$.

2) 山口昌一郎, 川上元郎：色彩工学入閒。オーム社, 東京, 1963.

3）川上元郎：色の常識。日本規格協会, 東京, 1966 . 
4) Edward, E.A. et al.: The pigments and color of living human skin. The American Journal of Anatomy, 16;13, 1939.

5) 近藤恒夫：色彩学. 理工图書, 東京, 1969.

6）児玉晃, 中田㿥子：色域の設定つついて, 皮膚色 表, 日本色彩研卶所, 東京, 1967.

7) 福田保：色の測定と応用。日刊工業新聞社, 東京, 1962 .
本諭文の要旨は第7回日本副腔学会飞招いて発表 した.

な祖图 2，图 4 は川上元郎氏の著慧より引用させてい たたいた。

（原稿受付 昭和49.9.2日） 